
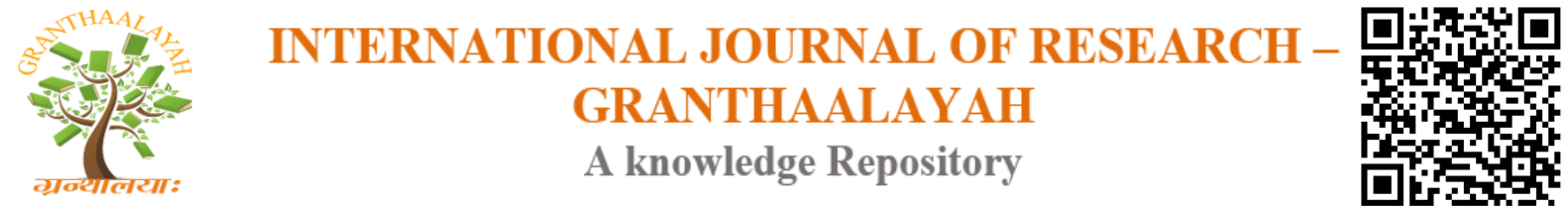

Science

\title{
INFLUENCE OF BOTANICALS ON SOIL FERTILITY POTENTIALS, SEED GERMINATION AND PERFORMANCE OF MAIZE (ZEA MAYS) VARIETIES UNDER LOW FERTILE CONTINUOUSLY-CROPPED SOIL CONDITIONS
}

\author{
Babajide Peter A. ${ }^{* 1}$, Opasina Ifeoluwa O. ${ }^{2}$, Ajibola Adijat T. ${ }^{1}$, Olla Noah O. ${ }^{3}$, Oyedele \\ Temitope A. ${ }^{4}$, Oyatokun, Olukayode S. 5 \\ ${ }^{* 1}$ Department of Crop Production and Soil Science, Ladoke Akintola University of Technology, \\ PMB 4000, Ogbomoso, Nigeria \\ ${ }^{2}$ Department of Crop Protection and Environmental Biology, University of Ibadan, Nigeria \\ ${ }^{3}$ Department of Agricultural Technology, Oyo State College of Agriculture and Technology, \\ PMB 10, Igboora, Oyo State, Nigeria \\ ${ }^{4}$ Department of Biology, the Polytechnic, Ibadan, Nigeria \\ ${ }^{5}$ Department of Agronomy, University of Ibadan, Nigeria
}

\begin{abstract}
It is not unreasonable to state that, even before the introduction of organic agriculture, African local farmers have numerous of undocumented environment-friendly, nature-inclined indigenous techniques for boosting soil fertility and enhancing crop yield. However, despite the versatility of indigenous knowledge, setback is always experienced from western science, which tags such knowledge as being non-scientific and not worthy of scholarly engagements. A field experiment was carried out in the year 2013, at the Teaching and Research Farms, Ladoke Akintola University of Technology, Ogbomoso, to assess the soil fertility and yield promoting potentials of some indigenous plant species' botanicals used as pre-planting treatments on different maize varieties. It was a 3 by 5 factorial experiment. The treatments introduced were: Three (3) maize varieties (V1 = ACR-DMR-SR-Y, V2 = Local EM-W and V3 = Suwan Solo Yellow and five (5) other treatments (comprising pre-sowing botanical treatments of: Kigelia africana only, Glyphea brevis only, combination of Kigelia africana and Glyphea brevis only, NPK fertilizer application (as a reference) and the control (treated with ordinary water only). The trial was laid out in Split Plot in Randomized Complete Block Design (RCBD), replicated three times. Data were collected on growth and yield parameters, and the data collected were analysed using analysis of variance (ANOVA). Means were compared using Duncan Multiple Range Test (DMRT). All the botanical treatments significantly influenced germination, growth, yield and nutrient uptakes of maize, compared to the control. Either of the botanicals tested (with ordinary basal manure application of the pre-existing plant residues on the field), competed effectively with NPK fertilized plants. Hence, since maize responded better to sole treatments of either Kigelia africana or Glyphea brevis extracts, irrespective of varieties than the combined treatment of the two botanicals, any of the maize varieties is therefore recommended as being suitably compatible
\end{abstract}


with either of the sole botanical treatments, in the study area. Thus, this research is reasonable, particularly in the aspects of fertilizer economy, environment-friendliness, organic farming and more profitable crop production in the tropics, where soils are continuously cropped and marginal.

Keywords: Maize; Indigenous Knowledge; Soil Fertility; Botanicals; Crop Performance.

Cite This Article: Babajide Peter A., Opasina Ifeoluwa O., Ajibola Adijat T., Olla Noah O., Oyedele Temitope A., and Oyatokun, Olukayode S.. (2017). "INFLUENCE OF BOTANICALS ON SOIL FERTILITY POTENTIALS, SEED GERMINATION AND PERFORMANCE OF MAIZE (ZEA MAYS) VARIETIES UNDER LOW FERTILE CONTINUOUSLY-CROPPED SOIL CONDITIONS." International Journal of Research - Granthaalayah, 5(11), 400-413. https://doi.org/10.29121/granthaalayah.v5.i11.2017.2374.

\section{Introduction}

Africa is a rich body of cultural and ecological diversities, which accommodates versatile cropplant species and a myriad of local ideas, trainings and practices termed African Indigenous Knowledge, on which Africans relied for solving specific problems relating to livelihood, development, health and environment, hundreds of years ago. Amongst the rural communities, the sharing of common Indigenous Knowledge systems with one another is a well-defined attribute particularly in terms of the principles, concepts and ideas behind their knowledge (Adedipe et al., 2004; Emeagwali and George, 2014). These include; land cultivation for crop production, hunting, fishing, trapping of birds and wild animals, construction of huts for living and granaries for maize storage), are well-valued and mostly task-based in nature (Fasunwon and Mabawonku, 2000), but not appreciated by western science which dismisses and tags them nonscientific and scholarly unacceptable (Adefarakan, 2011: Emeagwali and George, 2014). However, use of Agro-chemical treatments, particularly for various agricultural / farming activities had been reported harmful, unhygienic and even fatal (Fadina and Ogunyemi, 2002), hence, the persistence of poorer rural dwellers' livelihood, food insecurity, destitution, malnutrition and ill-health in Africa today. Therefore, there is an urgent need to conserve and promote our cultural values via sourcing for appropriate pre-existing Africa's Indigenous techniques, which will favourably improve the livelihood of rural dwellers and Africans' nutrition and health, which may deter African cultural cringe and erosion.

Maize (Zea mays) also known as corn is a monocotyledonous arable crop which belongs to the grass family Poaceae. It is one of the most important cereal crop grown in Africa and the third most cultivated crop in Nigeria. It ranks in order of importance to wheat and rice (FAO, 2000). Maize is commonly grown solely, or in combination with other arable crops like yam, cassava, cowpea, soybean etc. Also, it is commonly cultivated in the rainforest and savannah zones of Nigeria. Maize is a very important and highly versatile grain crop, which is grossly consumed domestically and industrially all over the World. It grains contains approximately $76-88 \%$ carbohydrate, $6-15 \%$ protein, $4.5-7.0 \%$ fat and $1.3 \%$ minerals as reported by (Klingman,1977). The maize kernel is made up of $83 \%$ of total dry weight, $11 \%$ germ, $5 \%$ pericarp and $1 \%$ pedicel (Okoruwa and Klingman, 1996). The proteins in the endosperm of maize are of three types which are prolamine, albumin and gluteling. Maize because of its high carbohydrate content it is 
used as food for human consumption, livestock feed and source of industrial raw materials for the production of oil, alcohol and starch (FAO, 2000).

African sausage tree (Kigelia africana) is a flowering African tree, belonging to the family Bignoniaceae. It is commonly characterized and easily recognised by its large (weighing $5-10 \mathrm{~kg}$ each, about 30-90 cm long and 7.5-10 cm in diameter) sausage-shaped fruits, usually found suspended on its strong branches. The generic name comes from the Mozambican name for sausage 'kigeli-keia'. The tree is about $2.5-18 \mathrm{~m}$ tall or sometimes a shrub of $2-3 \mathrm{~m}$ tall. The bark is smooth and greyish-brown in colour. The leaves are a group of three (trifoliate) at the end of branches and are 10-20 cm long with 3-8 leaflets. The inflorescence is a panicle, $(30-80 \mathrm{~cm}$ long). Its flower is tubular and dark red in colour with yellow veins which gives an unpleasant smell. The flower opens only at night, and mostly pollinated by nocturnal creatures like bat and hawk-moth. The plant is found across sub-Saharan tropical Africa as far as south of Africa (Roodt, 1992). The tree parts are used in diverse ways as anti-cancer, anti-inflammatory agent, breast firming, food supplements, treatment of wounds, manufacture of cosmetics etc. More so, in Kenya, Luo and Luhya people bury the fruit to symbolise the body of a lost person believed to be dead (Joffe, 2003).

African flexible tree (Glyphea brevis) belongs to the family Tiliaceae, it is a shrub and often used in making hedges because its roots form cuttings easily. The leaves are round and serrated and are slightly cordate at the base (Adams et al., 1986). The leaves have nerved venation, wide scariform, tuft domatia, fine lamina with stellate hairs beneath. The fruits are about $6 \mathrm{~cm}$ long, spindle-shaped with many longitudinal ridges and pointed at both ends (Adams et al., 1986: Adegoke et al., 2002). Glyphea brevis is very common in the under growth of closed forest, secondary jungles and river-banks. Also, in lowland to sub-mountain elevation throughout many regions of the world, and wide spread all over the tropical Africa. It is used medically as antidote against venomous stings and bites, liver treatment, stimulants and pain killer. It is also used as pesticides, particularly as insecticides and arachnicides (Adegoke et al., 2002). As one of the Indigenous knowledge approach, extracts from these two aforementioned African trees are used by local farmers for pre-planting treatments of seeds and or other crop propagules, aiming at promoting germinability, growth and yield of the concerned crop(s). Although, it is an unusual practice, but in most parts of Nigeria, those farmers practising it (either frequently or occasionally), know the applicability of this indigenous technology. Since, farmers testified verbally to the workability and sustainability of this indigenous knowledge as soil fertility enhancer as well as a crop growth and yield promoter, yet the documented facts on these desirable effects on important arable cereals like maize, had not been established or published by researchers. Since, soil fertility is a major hindrance to tropical crop production, and that the world is tending towards sustainable and environment-friendly farming techniques like organic farming, researching into farming techniques which promote soil fertility, crop growth and yield via simple pre-treatment of seeds with certain plant extracts, is a worthwhile and easily adoptable technology. Therefore, the objectives of this research are;

1) To assess the performance of maize cultivars subjected to pre-planting seed treatments with Kigelia africana and (or) Glyphea brevis extracts.

2) To evaluate the effects of these extracts on some soil physico-chemical properties and nutrient uptakes. 
3) To determine the variety of maize demonstrating optimum crop performance, regarding any of the pre-planting seed treatments received.

\section{Materials and Methods}

\subsection{Description of the Experimental Site}

The experiment was conducted at the Teaching and Research Farms, Ladoke Akintola University of Technology, Ogbomoso, Oyo State, Nigeria, between late July and early November, 2013, to assess the soil fertility and yield improving potentials of Kigelia africana and Glyphea brevis botanicals on different maize varieties. Ogbomoso is located on latitude $8^{\circ} 10^{\prime} \mathrm{N}$ and $4^{\circ} 10^{\prime} \mathrm{E}$ in the guinea savannah zone of south western Nigeria. Naturally, Ogbomoso is characterized by bimodal rainfall distribution. The early rains start in late March /early April and end in late July / early August, which is usually followed by a short dry spell in August. Also, the late rainy season spans between August and November, while the annual mean rainfall of the study area ranges between $1150 \mathrm{~mm}$ and $1250 \mathrm{~mm}$ (Babajide and Oyeleke, 2014). Although the experimental plot was earlier being subjected to continuous sole cropping with cassava and guinea corn on rotational basis for the past six years, there was neither bush burning nor overgrazing record by cattle, which are the common practices in the study area.

\subsection{Land Clearing and Preparation}

The land was manually cleared of the pre-existing vegetation, using hoe and cutlass. Each plot was then demarcated and constructed into bed. Each plot size was $1.5 \mathrm{~m} \times 2.0 \mathrm{~m}$ and the space between the beds was $1.0 \mathrm{~m} \times 1.0 \mathrm{~m}$. The space between the replicates was $1.5 \mathrm{~m} \times 1.5 \mathrm{~m}$. Also, the cleared weeds were carefully buried during construction of each bed, which served as basal manure application.

\subsection{Soil Sampling and Analyses}

During land preparation, pre-planting collection of soil samples was carried out. Also, the postcropping soil sampling was done after harvesting, by placing the soil auger at a depth of 0-15 $\mathrm{cm}$, across the farm plots, for laboratory analyses of the soil physical and chemical properties. It is necessary to indicate that, during the post cropping soil sampling exercise, plots which received NPK fertilizer application were exempted from being parts of the composite sample. From the collected soil samples, unwanted materials such as debris, steel, stone and other foreign particles were carefully removed. The composite auger sample was air dried, crushed and sieved through $2 \mathrm{~mm}$ and $0.5 \mathrm{~mm}$ meshes for the determination of particle size, $\mathrm{pH}(\mathrm{H} 2 \mathrm{O})$, total nitrogen $(\mathrm{N})$, organic carbon, and available phosphorous $(\mathrm{P})$, Iron $(\mathrm{Fe})$, copper $(\mathrm{Cu})$, zinc $(\mathrm{Zn})$, the exchangeable cations ( $\mathrm{Ca}, \mathrm{Na}, \mathrm{Mg}$ and $\mathrm{K}$ ). The particle size analysis was carried out according to the Bouyoucos (1951) hydrometer method, using sodium hexametaphosphate as the dispersant. Soil $\mathrm{pH}$ was determined in a 1:1 soil: water ratio and 2:1 soil: KCl ratio (IITA, 1982). Available phosphorus was determined using Bray and Kurtz P-1 method (Page et al., 1982). Total nitrogen was determined by the micro Kjeldal method (Bremner and Mulvaney, 1989). The exchangeable $\mathrm{K}$ and $\mathrm{Na}$ were determined using the EEL flame photometer while $\mathrm{Ca}$ and $\mathrm{Mg}$ were estimated using Versenate titration method, and the organic carbon was determined using 
the Walkley and Black method (Nelson and Summers, 1982). The soil textural class was determined from the soil textural triangle.

\subsection{Treatments and Experimental Design}

It was a 3 by 5 factorial experiment, involving three (3) maize varieties (V1= ACR-DMR-SR-Y, V2 = LOCAL EM-W and V3 = SUWAN SOLO YELLOW and five (5) other treatments (three pre-sowing botanical treatments comprising Kigelia africana only, Glyphea brevis only and Kigelia africana + Glyphea brevis, then, NPK fertilizer application (as a reference) and the control (treated with ordinary water only). The trial was laid out in Split Plot in Randomized Complete Block Design (RCBD), replicated three times. The pre-sowing treatments were originally prepared by squeezing the leaf samples in water thoroughly (on the basis of $500 \mathrm{~g}$ each of the leaf samples 1.0 litre of water). The combined solution was prepared by using half dosages of $250 \mathrm{~g}$ each of the leaf samples (Kigelia africana and Glyphea brevis) in 0.5 litre of water each. All the prepared solutions were then carefully filtered with mosquito net materials, to separate the leaf sample remnants / residues from the filtrates or solutions, which were required for the experiment. The combined solutions in half dosages were then mixed thoroughly together. The solutions were made in batches based on the dilution procedures (of $500 \mathrm{~g}$ of the leaf sample to 1.0 litre of water), to meet the required quantities of seed to be treated. Each of the filtrates was poured into respective plastic containers in which seeds were well soaked overnight. It should be noted that the solutions or filtrates were allowed to overflow all the seeds inside each container. The solutions were then carefully decanted early in the morning, so that the seeds were separated for proper air drying for at least one (1) hour before sowing. No other pre-planting chemicals were added to the seeds at all. The control was also prepared by soaking the seeds inside ordinary water overnight and then carefully decanted early in the morning, so that, the seeds were removed for proper air drying as indicated earlier for other treatment solutions.

\subsection{Propagation and Agronomic Practices}

After being treated accordingly, the viable maize seeds from three different varieties (ACR9931-DMR-SR-YELLOW, LOCAL EM-WHITE, SUWAN SOLO YELLOW), were sown respectively at (3) seeds per hole. Thinning to one seed per hole was done at two weeks of sowing. This experiment was purely a rain-fed type requiring no artificial watering throughout. Manual weeding was done using hoes. Basal manure application was done by carefully burying the plant residues found on the plots (except those plots to be fertilized with NPK), during land preparation (i.e. making beds). Application of NPK 15-15-15 fertilizer was done at the rate of $400 \mathrm{~kg}$ Nha-1 at three (3) weeks after sowing, to the respective plots only.

\subsection{Germinability Trial}

After the respective pre-planting treatments of the seeds, one hundred seeds per treatment were selected and arranged in completely randomised design, (CRD), replicated three times. The seeeds were sown in soil filled experimental pots. This experiment was conducted to determine the likely effect of these treatments on seed germinability. The experiment was monitored for four (4) days only and was terminated immediately. The seed germinability was determined using a formular: 


$$
\text { Germinability }=\underset{\substack{\text { Total number of germinated seeds } \\ \text { Total of seeds sown }}}{X} 100
$$

\subsection{Data Collection}

Data were collected on some maize growth and yield parameters. Data collection on growth parameters commenced at ten week after sowing (10 WAS) on: plant height, stem circumference, leaf length and leaf width. Plant height was determined by using measuring tape placed at the above ground base of the plant and allowed to run to the plant's tip), stem girth (by using venier calipers place at the $20 \mathrm{~cm}$ height of each plant, the value obtained was referred to as the stem diameter, which was later converted to girth or circumference by a fomular: $\pi \mathrm{D}$ (i.e.3.142 multiplied by the original diameter (D) value as obtained from the reading with the venier calipers). Also determined were leaf length and leaf width. The leaf length was by directly placing the measuring tape on the base of selected leaf and run it on the surface of the leaf to the apex, while the leaf width was determined by placing the measuring tape horizontally at exactly $10 \mathrm{~cm}$ point from the base of each of the selected leaves. However, at the termination of the experiment, the yield parameters measured were ear fresh weight, cob dry weights, grain dry weight, above ground and below ground biomass dry weights, using Mp $600 \mathrm{H}$ electronic weighing balance.

\subsection{Plant Sampling and Analysis}

Harvesting of maize cobs commenced on 92nd day after sowing. Harvesting was done manually by plucking with hands. Immediately after the termination of the experiment, the harvested plant samples were first weighed, using an electronic weighing balance of model Citizen $\mathrm{Mp} 600 \mathrm{H}$, to determine the sample dry weights. The samples were later oven dried at $80^{\circ} \mathrm{C}$ for 72 hours to a constant weight, according to the procedures described by IITA (1982) and Babajide et al (2012), followed by the determination of nutrient concentrations and uptakes. Total $\mathrm{N}$ was determined by micro-Kjeldahl method. The $\mathrm{P}$ was determined using vanadomolybdate colorimetry, and $\mathrm{K}$ by flame photometry. The nutrients accumulated in plant parts were then calculated as; Nutrient uptakes $=\%$ Nutrient content X sample dry weight (Ombo, 1994: Gungula, 1999).

\subsection{Statistical Analysis}

All data collected were subjected to analysis of variance (ANOVA). The means were separated using Duncan's Multiple Range Test (DMRT) at 5\% probability level (SAS, 2013).

\section{Results and Discussion}

\subsection{Soil Physical and Chemical Characteristics}

The results from the pre-cropping soil physico-chemical analyses showed that the soil was sandy-loam in nature. The soil sample was also slightly acidic and grossly low in major nutrient concentrations. These results were in line with the earlier research findings of Babajide and Fagbola (2014) and Babajide et al (2017), who reported that the soils in the study area were major low in essential nutrient concentrations and could not effectively support proper growth 
and development of most arable crops, without applying any suitable amounts of either organic manure or synthetic fertilizer (Table 1). Also, certain scientifically inexplicable improvements were observed in the post-cropping values of some soil physico-chemical properties such as the soil $\mathrm{pH}$ and some nutrients, compared to the pre-cropping values, particularly the organic $\mathrm{C}, \mathrm{N}, \mathrm{P}$ and $\mathrm{K}$, while the values of other soil properties were either constant or slightly lower (Table 1). Both the pre-cropping and post-cropping soil samples were found to be texturally sandy loam in nature (Table 1). These results were also corroborating the reports of Olatunji et al (2012) and Babajide and Oyeleke (2014), who reported that most soils in the study area are marginal and texturally in the sandy loam class.

Table 1: Results of the Pre and Post-cropping Physico-chemical Analysis of the Soil Sample

\begin{tabular}{|c|c|c|}
\hline \multirow[t]{2}{*}{ Soil Properties } & \multicolumn{2}{|c|}{ Values } \\
\hline & (Pre-cropping) & (Post-cropping) \\
\hline $\mathrm{pH}\left(\mathrm{H}_{2} \mathrm{O}\right)$ & 6.00 & 6.10 \\
\hline Total $\mathrm{N}\left(\mathrm{gkg}^{-1}\right)$ & 0.36 & 0.42 \\
\hline Organic carbon $\left(\mathrm{gkg}^{-1}\right)$ & 4.38 & 4.36 \\
\hline Available P $\left(\mathrm{mgkg}^{-1}\right)$ & 3.26 & 3.32 \\
\hline Exchangeable K $\left(\mathrm{cmolkg}^{-1}\right)$ & 0.26 & 0.28 \\
\hline $\mathrm{Fe}(\mathrm{mg} \mathrm{kg}-1)$ & 1.10 & 1.10 \\
\hline $\mathrm{Cu}(\mathrm{mg} \mathrm{kg}-1)$ & 2.20 & 2.20 \\
\hline $\mathrm{Zn}(\mathrm{mg} \mathrm{kg-1})$ & 2.16 & 2.15 \\
\hline Exchangeable $\mathrm{Na}$ (cmol kg-1) & 0.26 & 0.28 \\
\hline Exchangeable $\mathrm{Ca}(\mathrm{Cmol} \mathrm{kg-1})$ & 0.16 & 0.19 \\
\hline Exchangeable $\mathrm{Mg}\left(\mathrm{Cmol} \mathrm{kg}_{-1}\right) 3.1$ & 2.56 & 2.54 \\
\hline Sand $(\%)$ & 89.10 & 87.31 \\
\hline Silt $(\%)$ & 7.60 & 9.01 \\
\hline Clay $(\%)$ & 3.30 & 3.68 \\
\hline Textural class & Sandy loam & Sandy loam \\
\hline
\end{tabular}

\subsection{Effects of Pre-planting Botanical Treatments on Germinability of Maize}

This trial was originally conducted to determine the effects of the introduced treatments on seed germinability. All plant extract treatments introduced significantly improved maize seed germinability, compared to the ordinary water treatment, which served as the control (Table 2). The experiment was monitored for four days only before being terminated. This is because the further prolongation of the days for the experiment may alter the validity of the experiment, since soaking in water is scientifically believed to promote seed germination. Although, determination of the chemical composition of these plant leaf extracts was beyond the scope of this experiment, yet it is an eye opener to researchers in the aspect of seed dormancy breaking. However, these results were in supprt of the earlier research reports of Baiyeri and Mbah (2006), Hartmann et al (2007) and Dickens (2011) who indicated the significance of water in dormancy breaking of many dormant tropical plant seeds. Oyerinde et al. (2009) also presented corroborative report that the fresh aqueous shoot extracts of $\mathrm{T}$. diversifolia did not significantly inhibit the germination of maize. More so, the results of Chukwuka et al. (2014)were in contrary to these research findings as they reported that the aqueous extracts of Tithonia diversifolia (Mexican 
sunflower) and Vernonia amygdalina (Bitter leaf) inhibited maize seed germination percentage, as well as the plumule and radical growth of the maize seedlings.

Table 2: Effects of pre-planting seed treatments on germinability of Maize (Zea mays)

\begin{tabular}{ll}
\hline Treatments & Germinability (\%) \\
& \\
\hline V1 + Kigelia africana & $100.0 \mathrm{a}$ \\
V1 + Glyphea brevis & $97.2 \mathrm{a}$ \\
V1 + Kigelia africana + Glyphea brevis & $97.8 \mathrm{a}$ \\
V1+ Water (control) & $80.0 \mathrm{~b}$ \\
VI + NPK & Not determined \\
V2 + Kigelia africana & $100.0 \mathrm{a}$ \\
V2 + Glyphea brevis & $98.8 \mathrm{a}$ \\
V2 + Kigelia africana + Glyphea brevis & $97.8 \mathrm{a}$ \\
V2 + Water (control) & $81.2 \mathrm{~b}$ \\
V2 + NPK & Not determined \\
V3 + Kigelia africana & $100.0 \mathrm{a}$ \\
V3 + Glyphea brevis & $98.8 \mathrm{a}$ \\
V3 + Kigelia africana + Glyphea brevis & $97.8 \mathrm{a}$ \\
V3+ Water (control) & $82.6 \mathrm{~b}$ \\
VI3+ NPK & Not determined \\
\hline Mean followed by same letters are not significantly different at 5\% probability level, using Duncan's Multiple Range Test (DMRT). V1= ACR- \\
DMR-SR-Y, V2 = LOCAL EM-W and V3=SUWAN SOLO YELLOW
\end{tabular}

\subsection{Pre-planting Seed Treatments by Botanicals and Growth Parameters of Maize (Zea mays)}

Application of botanical pre-planting treatments significantly enhanced growth parameters of maize, irrespective of the varieties (Table 3). Plants from variety 3 (SUWAN SOLO YELLOW) which received NPK fertilizer application had the highest significant value of plant height $(230.3 \mathrm{~cm})$, which was not significantly different from $228.0 \mathrm{~cm}$, obtained from those plants which received pre-planting Kigelia africana treatment. These values were observed to be significantly higher than those of the plants which received pre-planting treatments of Glyphea brevis treatment, and a combination of Kigelia africana and Glyphea brevis, while the control had the least value (Table 311). Similar trend was observed across all the varieties with either Kigelia brevis treated or NPK fertilized plants having significantly higher value of plant height, which were not significantly different from each other, followed by Glyphea brevis treated and the combined botanical pre-planting treatment, while the control had the least (Table 3). Regarding the stem girth or circumference, it was observed that variety 1 (ACR-DMR-SR-Y) which received Kigelia africana treatment significantly produced the widest stem circumference or girth. Although, the value was not significantly different from that of NPK fertilized maize, it was significantly higher than those of Glyphea brevis treated and the treatment combination of Kigelia africana and Glyphea brevis, while the control had the narrowest stem circumference (Table 3). Also, for variety 2 (LOCAL EM-W), the Kigelia africana treated plants produced significantly higher value of stem circumference $(12.8 \mathrm{~cm})$. This value was not significantly different from those of NPK fertilized maize plants, as well as the Glyphea brevis treated and the combination of the two botanicals, but significantly higher than the water treated or control which had the least value of stem circumference. Also, in variety 3 , the Kigelia africana treated 
maize plants produced the significantly wider value of stem circumference $(12.4 \mathrm{~cm})$ which was statistically similar to the NPK fertilized $(11.2 \mathrm{~cm})$, followed by the Kigelia africana treated and the combined botanicals, while the control had the least (Table 3). Leaf length and width, were significantly influenced by application of all the pre-planting seed treatments tested (Table 3). Application of Kigelia africana treatment significantly influenced leaf length and width. The values of Kigelia africana treated were statistically similar to those obtained from the NPK fertilized plants across the varieties. The values obtained were significantly higher than the other treatments tested, while the control had the least values of leaf length and width (Table 3). All these results are in support of Taiwo and Makinde (2005) who reported positive response of cowpea to both shoot and root aqueous extracts of $\mathrm{T}$. diversifolia as indicated in its enhanced growth and development. Although, Alabi et al. (2005) reported that aqueous extracts of many plants including $\mathrm{V}$. amygdalina improved the leaf area index (LAI) of cowpea under field conditions, Chukwuka et al. (2014) reported in contrary that the highest stem girths were recorded in plants which received NPK application throughout their research study.

Table 3: Growth Parameters of Maize (Zea mays) as Influenced by Botanical Pre-planting Seed Treatments

\begin{tabular}{|c|c|c|c|c|}
\hline Treatments & $\begin{array}{l}\text { Plant height } \\
(\mathrm{cm})\end{array}$ & $\begin{array}{l}\text { Stem girth } \\
(\mathrm{cm})\end{array}$ & $\begin{array}{l}\text { Leaf length } \\
(\mathrm{cm})\end{array}$ & $\begin{array}{l}\text { Leaf width } \\
(\mathrm{cm})\end{array}$ \\
\hline $\mathrm{V} 1+$ Kigelia africana & $222.6 \mathrm{a}$ & $12.1 \mathrm{a}$ & $98.8 \mathrm{a}$ & $11.7 \mathrm{a}$ \\
\hline $\mathrm{V} 1+$ Glyphea brevis & $191.3 b$ & $9.6 b$ & $76.2 b$ & $8.2 b$ \\
\hline $\mathrm{V} 1+$ Kigelia africana + Glyphea brevis & $172.0 \mathrm{c}$ & $9.2 b$ & $73.4 b$ & $8.4 \mathrm{~b}$ \\
\hline V1+ Water (control) & $126.5 d$ & $4.9 \mathrm{c}$ & $62.2 \mathrm{c}$ & $5.8 \mathrm{c}$ \\
\hline $\mathrm{VI}+\mathrm{NPK}$ & $226.2 \mathrm{a}$ & $10.3 \mathrm{ab}$ & $94.3 \mathrm{a}$ & $10.4 \mathrm{a}$ \\
\hline $\mathrm{V} 2+$ Kigelia africana & $215.4 \mathrm{a}$ & $12.8 \mathrm{a}$ & $96.8 \mathrm{a}$ & $9.7 \mathrm{ab}$ \\
\hline $\mathrm{V} 2+$ Glyphea brevis & $192.7 b$ & $9.4 b$ & $85.2 \mathrm{ab}$ & $8.2 b$ \\
\hline $\mathrm{V} 2+$ Kigelia africana + Glyphea brevis & $167.5 \mathrm{c}$ & $9.3 b$ & $60.2 \mathrm{c}$ & $8.2 b$ \\
\hline $\mathrm{V} 2+$ Water (control) & $128.2 d$ & $5.6 \mathrm{c}$ & $57.3 \mathrm{~cd}$ & $5.1 \mathrm{c}$ \\
\hline $\mathrm{V} 2+\mathrm{NPK}$ & $224.5 \mathrm{a}$ & $10.2 \mathrm{ab}$ & $92.1 \mathrm{a}$ & $9.8 \mathrm{ab}$ \\
\hline $\mathrm{V} 3+$ Kigelia africana & $228.0 \mathrm{a}$ & $12.4 \mathrm{a}$ & $102.1 \mathrm{a}$ & $11.2 \mathrm{a}$ \\
\hline $\mathrm{V} 3+$ Glyphea brevis & $190.5 b$ & $9.2 b$ & $87.3 \mathrm{ab}$ & $8.1 \mathrm{~b}$ \\
\hline $\mathrm{V} 3+$ Kigelia africana + Glyphea brevis & $161.0 \mathrm{c}$ & $10.1 b$ & $71.8 b$ & $8.3 b$ \\
\hline V3+ Water (control) & $129.6 \mathrm{~d}$ & $5.0 \mathrm{c}$ & $58.8 \mathrm{~cd}$ & $5.3 \mathrm{c}$ \\
\hline $\mathrm{V} 3+\mathrm{NPK}$ & $230.3 \mathrm{a}$ & $11.2 \mathrm{ab}$ & $92.1 \mathrm{a}$ & $12.1 \mathrm{a}$ \\
\hline
\end{tabular}

Mean followed by same letters are not significantly different at 5\% probability level, using Duncan's Multiple Range Test (DMRT). V1= ACRDMR-SR-Y, V2=LOCALEM-W and V3=SUWANSOLOYELLOW

\subsection{Pre-planting Seed Treatments by Botanicals and Yield Parameters of Maize (Zea mays)}

Application of pre-planting treatment botanicals significantly enhanced maize yield parameters. The fresh ear weight of maize produced was significantly higher with respect to Kigelia africana treatment (Table 4). Although there was no statistical dissimilarity in the means of both the NPK fertilized and the combined botanical treatment, their mean values obtained were significantly higher than the Glyphea brevis treated. For variety 2 (LOCAL EM-W) and variety 3 (SUWAN 
SOLO YELLOW), the significantly higher values of fresh ear weight were observed in NPK fertilized plants, followed by the statistically similar values of the Kigelia africana treated and the treatment combination of the two botanicals, while the water treated (control) had the least fresh ear weight value (Table 4). For variety 1 , dry cob weight was significantly improved by Kigelia africana treatment. The value was not significantly different from other treatments tested (except the control which had the least value). Meanwhile, for the variety 2 and 3, application of NPK significantly influenced dry cob weight of maize. The value obtained was found to be statistically indifferent from those obtained in both the Kigelia africana and Glyphea brevis treated plants, but significantly higher than the combined pre-planting botanical treatment and the water treated (the control), which had the least value. In relation to the biomass production of maize, application of different pre-planting botanical treatments significantly enhanced both the dry below ground and above ground biomass weights (Table 4). In general, all the pre-planting botanical treatments tested significantly improved biomass yields of maize, irrespective of the varieties involved, compared to the control (Table 4). These results were in agreement with Alabi et al. (2005) who reported that fresh and dry leaf aqueous extracts of V. amygdalina significantly improved the yield of cowpea plants in terms of pod and grain weights. Also, these research results partly corroborated the research findings of Chukwuka et al. (2014) which indicated positive yield responses of maize to different aqueous extracts of T. diversifolia, as the highest cob yield being observed in seedlings treated with $50 \% \mathrm{w} / \mathrm{v}$ aqueous extracts of $\mathrm{T}$. diversifolia. In addition, these research results partly contradicted the research findings of Chukwuka et al. (2014), who reported insignificant effects of the aqueous extracts of V. amygdalina on the yield of the maize.

Table 4: Yield Parameters of Maize (Zea mays) as Influenced by Botanical Pre-planting Seed Treatments

\begin{tabular}{|c|c|c|c|c|c|}
\hline \multirow[t]{2}{*}{ Treatments } & Ear $\quad$ Fresh & Cob Dry & Grain Dry & Below-ground & Above-ground \\
\hline & $\begin{array}{l}\text { Weight } \\
\left(\mathrm{g}_{\text {plant }}{ }^{-1}\right)\end{array}$ & $\begin{array}{l}\text { Weight } \\
\text { (g plant } \\
\left.{ }^{1}\right)\end{array}$ & $\begin{array}{l}\text { Weight } \\
\left(\text { g plant }^{-1}\right)\end{array}$ & $\begin{array}{l}\text { Biomass Dry } \\
\text { weight } \\
\quad\left(\mathrm{g} \text { plant }^{-1}\right)\end{array}$ & $\begin{array}{l}\text { Biomass Dry } \\
\text { weight } \\
\left.\quad \text { (g plant }^{-1}\right)\end{array}$ \\
\hline $\mathrm{V} 1+$ Kigelia africana & $342.8 \mathrm{a}$ & $27.1 \mathrm{a}$ & $198.8 \mathrm{a}$ & $39.9 a$ & $302.6 \mathrm{a}$ \\
\hline $\mathrm{V} 1+$ Glyphea brevis & $241.2 b$ & $19.6 \mathrm{ab}$ & $176.2 b$ & $42.2 \mathrm{a}$ & $262.2 \mathrm{a}$ \\
\hline $\begin{array}{l}\mathrm{V} 1+\text { Kigelia africana }+ \\
\text { Glyphea brevis }\end{array}$ & $332.4 \mathrm{a}$ & $19.2 \mathrm{ab}$ & $173.4 \mathrm{~b}$ & $42.4 \mathrm{a}$ & $254.7 \mathrm{ab}$ \\
\hline V1+ Water (control) & $126.6 \mathrm{c}$ & $11.9 \mathrm{c}$ & $102.2 \mathrm{c}$ & $29.6 b$ & $92.8 \mathrm{c}$ \\
\hline $\mathrm{VI}+\mathrm{NPK}$ & $324.4 \mathrm{a}$ & $25.8 \mathrm{a}$ & $194.3 \mathrm{a}$ & $45.4 \mathrm{a}$ & $300.3 \mathrm{a}$ \\
\hline $\mathrm{V} 2+$ Kigelia africana & $325.6 \mathrm{a}$ & $27.8 \mathrm{a}$ & $196.8 \mathrm{a}$ & $44.7 \mathrm{a}$ & $292.4 \mathrm{a}$ \\
\hline $\mathrm{V} 2+$ Glyphea brevis & $236.8 b$ & $19.4 b$ & $195.8 \mathrm{a}$ & $43.2 \mathrm{a}$ & $288.6 \mathrm{a}$ \\
\hline $\begin{array}{l}\mathrm{V} 2+\text { Kigelia africana }+ \\
\text { Glyphea brevis }\end{array}$ & $242.8 b$ & $19.3 b$ & $172.2 b$ & $41.2 \mathrm{a}$ & $292.4 a$ \\
\hline $\mathrm{V} 2+$ Water (control) & $132.6 \mathrm{c}$ & $12.6 \mathrm{c}$ & $106.3 \mathrm{c}$ & $30.1 b$ & $101.5 \mathrm{c}$ \\
\hline $\mathrm{V} 2+\mathrm{NPK}$ & $330.2 \mathrm{a}$ & $20.2 \mathrm{ab}$ & 208.1a & $42.8 \mathrm{a}$ & $282.8 \mathrm{a}$ \\
\hline $\mathrm{V} 3+$ Kigelia africana & $341.6 \mathrm{a}$ & $22.4 \mathrm{ab}$ & $212.1 \mathrm{a}$ & $42.2 \mathrm{a}$ & $304.4 \mathrm{a}$ \\
\hline $\mathrm{V} 3+$ Glyphea brevis & $248.2 b$ & $19.2 \mathrm{ab}$ & $168.3 b$ & $41.1 \mathrm{a}$ & $286.9 a$ \\
\hline $\begin{array}{l}\mathrm{V} 3+\text { Kigelia africana }+ \\
\text { Glyphea brevis }\end{array}$ & $231.4 b$ & $20.1 \mathrm{ab}$ & $171.8 \mathrm{~b}$ & $43.3 \mathrm{a}$ & $249.9 \mathrm{ab}$ \\
\hline
\end{tabular}




\begin{tabular}{lccccc}
\hline V3+ Water (control) & $118.7 \mathrm{c}$ & $12.0 \mathrm{c}$ & $108.8 \mathrm{c}$ & $30.3 \mathrm{~b}$ & $106.2 \mathrm{c}$ \\
V3+ NPK & $350.6 \mathrm{a}$ & $26.2 \mathrm{a}$ & $202.1 \mathrm{a}$ & $39.8 \mathrm{a}$ & $289.1 \mathrm{a}$ \\
\hline \multicolumn{2}{l}{ Mean followed by same letters are not significantly different at 5\% probability level, using Duncan's Multiple Range Test (DMRT). V1 } \\
ACR-DMR-SR-Y, V2 = LOCAL EM-W and V3 =SUWAN SOLO YELLOW
\end{tabular}

\subsection{Pre-planting Seed Treatments by Botanicals and Nutrient Uptakes of Maize (Zea mays)}

Pre-planting treatment by botanicals significantly enhanced nutrient uptakes of maize, irrespective of the varieties concerned (Table 5). The N, P and K uptakes were significantly improved by all the pre-planting botanical treatments introduced. Although, there were no statistical differences between the nutrient uptake values of solely applied botanicals (either Kigelia africana or Glyphea brevis only), and the NPK fertilized, the values were found to be significantly higher than the combined botanical treatments, followed by the water treated (or the control), which had the least values of $\mathrm{N}, \mathrm{P}$ and $\mathrm{K}$ uptakes (Table 4). These results were in support of some researchers' reports (Taiwo and Makinde, (2005); Olabode et al., (2007); Babajide et al. (2012); Chukwuka et al. (2014), who emphasized improved soil nutrition and plant nutrient concentrations, as being traceable to the soil fertilizing potentials of some applied tropical plant extracts or plant parts.

Table 5: Nutrient uptakes of maize (Zea mays) as influenced by botanical pre-planting seed treatments

\begin{tabular}{|c|c|c|c|}
\hline \multirow[t]{2}{*}{ Treatments } & \multicolumn{3}{|c|}{ Nutrient Uptakes (gkg- $\left.{ }^{1}\right)$} \\
\hline & $\mathbf{N}$ & $\mathbf{P}$ & $\mathbf{K}$ \\
\hline $\mathrm{V} 1+$ Kigelia africana & $5.6 \mathrm{a}$ & $0.7 \mathrm{a}$ & $1.2 \mathrm{a}$ \\
\hline $\mathrm{V} 1+$ Glyphea brevis & $5.2 \mathrm{a}$ & $0.6 \mathrm{a}$ & $1.2 \mathrm{a}$ \\
\hline $\mathrm{V} 1+$ Kigelia africana + Glyphea brevis & $4.8 \mathrm{a}$ & $0.5 \mathrm{ab}$ & $0.8 \mathrm{~b}$ \\
\hline V1+ Water (control) & $2.1 b$ & $0.3 \mathrm{c}$ & $0.4 \mathrm{c}$ \\
\hline $\mathrm{VI}+\mathrm{NPK}$ & $6.1 \mathrm{a}$ & $0.8 \mathrm{a}$ & $1.3 \mathrm{a}$ \\
\hline $\mathrm{V} 2+$ Kigelia africana & $6.0 \mathrm{a}$ & $0.6 \mathrm{a}$ & $1.2 \mathrm{a}$ \\
\hline $\mathrm{V} 2+$ Glyphea brevis & $5.1 \mathrm{a}$ & $0.4 \mathrm{~b}$ & $1.1 \mathrm{a}$ \\
\hline $\mathrm{V} 2+$ Kigelia africana + Glyphea brevis & $4.6 \mathrm{a}$ & $0.5 \mathrm{ab}$ & $0.9 \mathrm{ab}$ \\
\hline $\mathrm{V} 2+$ Water (control) & $2.4 \mathrm{~b}$ & $0.2 \mathrm{c}$ & $0.3 \mathrm{c}$ \\
\hline $\mathrm{V} 2+\mathrm{NPK}$ & $4.7 \mathrm{a}$ & $0.7 \mathrm{a}$ & $1.1 \mathrm{a}$ \\
\hline $\mathrm{V} 3+$ Kigelia africana & $5.2 \mathrm{a}$ & $0.7 \mathrm{a}$ & $1.2 \mathrm{a}$ \\
\hline $\mathrm{V} 3+$ Glyphea brevis & $4.9 \mathrm{a}$ & $0.7 \mathrm{a}$ & $1.0 \mathrm{a}$ \\
\hline $\mathrm{V} 3+$ Kigelia africana + Glyphea brevis & $4.4 \mathrm{a}$ & $0.5 \mathrm{ab}$ & $0.8 \mathrm{~b}$ \\
\hline V3+ Water (control) & $2.2 b$ & $0.3 \mathrm{c}$ & $0.5 \mathrm{c}$ \\
\hline
\end{tabular}

\section{Conclusion}

Maize responded well to the use of leaf extracts as pre-planting seed treatments. Application of either sole or combined botanical significantly enhanced seed germination and emergence, as well as the growth, yield and nutrient uptakes of maize, compared to the control. Also, the 
botanically-treated maize plants effectively and significantly competed with the NPK fertilized plants. The soil fertility improvement and the growth and yield promoting attributes of these leaf extracts (which were exhibited despite the fact that they were not directly applied to the plants or soil as amendments on the field), were scientifically inexplicable. Hence, since maize responded better to sole treatments of either Kigelia africana or Glyphea brevis extracts, than a combination of the two botanicals, irrespective of the varieties, the pre-planting seed treatment using any of the maize varieties is therefore recommended for farmers in the study area. Thus, incorporation of such indigenous knowledge into crop production is a worthwhile technology, which could be easily exploited for organic farming, fertilizer economy, and for discouragement or alleviation of total dependence on chemical inputs for tropical crop production. This may also promote environment friendliness for sustainable and hygienic crop production.

\section{References}

[1] Adams, R.T., Ogbonnia, S. J. and Van Staden (1986). Anticonvulsant effects of Glyphea brevis (speng) Moraches leaf extracts in mice and preliminary phyto-chemical tests. Nigeria Quarterly Journal of Hospital Medicine (NQJHM) Vol. 13 (3-4) pp 62-64.

[2] Adedipe, N.O.; Okuneye, P.A.and I.A. Ayinde. (2004). The Relevance of Local and Indigenous Knowledge for Nigerian Agriculture. Paper Presented at the International Conference on Bridging Scales and Epistemologies: Linking Local Knowledge with Global Science in Multiscale Assessments. March 16-19, Alexandria, Egypt.

[3] Adefarakan, T. (2011). Reconceptualising the indigenous from anti-colonial and Black feminist perspectives: Living and imagining indigeneity differently. In Indigenous Philosophies and Critical Education. New York: Peter Lang. pp. 34-52.

[4] Adegoke, T.Y., Ogbonnia, S. and Coker, H.A. (2002). Fauna and Flora of Liberia and their uses. FRPS (49 (1): 48-50.

[5] Alabi, D.A., Oyero, I.A., Jimoh and Amusa, N.A. (2005): Fungitoxic and phytotoxic effects of Vernonia amygdalina Del., Bryophyllum pinnantus Kurz, Ocimum gratissimum (Closium) L. and Eucalyptna globules (Caliptos) Labill water extracts on cowpea and cowpea seedling pathogens in Ago-Iwoye, South Western Nigeria. World Journal of Agricultural Sciences 1(1):70-75.

[6] Ayinde, I.A. (2004). Socio-economic and Health Effects of Pesticide Use in Cowpea-based Production Systems in Kano and Ogun States, Nigeria. Draft PhD Dissertation. Department of Agricultural Economics and Farm Management, University of Agriculture, Abeokuta, Nigeria.

[7] Babajide, P. A. and O. Fagbola (2014). Growth, yield and nutrient uptakes of sesame (Sesamum indicum linn.) as influenced by bio-fertilizer inoculants. International Journal of Current Microbiology and Applied Sciences. ISSN: 2319-7706. Vol.3. No.3 (8): 859-879.

[8] Babajide, P. A.; Ajibola, A.T.; Oyeleye, A. D.; Gbadamosi, T. S. and Olla, N. O. (2017).Growth, herbage yield and nutrient uptakes of indigenous jute mallow (Corchorus olitorius) as influenced by different fertilizer sources under dry season alfisols conditions. International Journal of Natural and Applied Sciences. IRJNAS ISSN; 2349-4077. Vol. 4 (5): 1-12

[9] Babajide, P. A.; Akanbi, W. B; Olabode, O. S., Olaniyi, J. O. and Ajibola, A.T. (2012). Influence of pre-application handling techniques of Tithonia diversifolia Hemsl. A. Gray residues on growth, seed yield and oil content of sesame (Sesamum indicum 1.), in south-western Nigeria. Journal of Animal and Plant sciences: Biosciences: Vol.15 (2): 2135-2146.

[10] Babajide, P.A. and Oyeleke, O.R. (2014). Evaluation of Sesame (Sesamum indicum Linn.) for Optimum Nitrogen Requirement under Usual Farmers' Practice of Basal Organic Manuring in the Savanna Ecoregion of Nigeria. Journal of Natural Science Research. ISSN online 2224-0921 Vol. 4 (17): 122 - 132. 
[11] Baiyeri K.P. and Mbah, B.N. (2006). Effects of soilless and soil based nursery media on seedling emergence, growth and response to water stress of African breadfruit (Treculia Africana Decne). African Journal of Biotechnology, 5: 1405-1410.

[12] Bouyoucos, G.J. (1951). A recalibration of the hydrometer method for making mechanical analysis of soils. Agronomy Journal 43: 434-438.

[13] Bremner, J.M. and Mulvaney C.S. (1989). Total Nitrogen in methods of soil Analysis Part 2. A.L. Page et al.,. American Society of Agronomy, Madison W.Pp. 595-624.

[14] Chukwuka, K.S., Obiakara, M. C. and I.A. Ogunsumi (2014). Effects of aqueous plant extracts and inorganic fertilizer on the germination, growth and development of maize (zea mays 1.). Journal of Agricultural Sciences. Vol. 59 (3): 243-254.

[15] Dickens D. (2011). Effect of propagation media on germination and seedling performance of Irvingia wombolu (Vermoesen). American Journal of Biotechnology and Molecular Science. ISSN Print: 2159-3698, Online ISSN: 2159-3701. Vol. 1(2): 51-56.

[16] Emeagwali, G. and George J. Sefa Dei (2014). African Indigenous Knowledge and the Disciplines: Anticolonial Educational Perspectives for Tranformative Change. Sense Publishers, Rotterdam, The Netherlands. https://www.sensepublishers.com/ ISBN 978-94-6209-770-4.

[17] Fadina, O.O. and S. Ogunyemi. 2002. The Potentials of Farmers' Indigenous Knowledge for the Control of Plant Diseases, 232-233. In: Linking Formal and Informal Science for Sustainable Development. Proceedings of the Gender and Science and Technology Association Regional Conference, Abuja, Nigeria, pp. 418.

[18] Fasunwon, O.O. and A.O. Mabawonku. (2000). Culture and Science Development in Nigeria, 6878. In: Linking Formal and Informal Science for Sustainable Development. Proceedings of the Gender and Science and Technology Association Regional Conference, Abuja, Nigeria, pp. 418.

[19] Food and Agriculture Organization (2000). Corporate document respository on maize in human nutrition. Journal of tropical Agriculture on tripartite hypothesis. Euphytica 1:271-279.

[20] Gungula D.T. 1999: Growth and nitrogen use efficiency in Mays (Zea may L.). In the Southern Guinea Savanna of Nigeira, Ph.D. Thesis University of Ibadan Nigeria 181pp.

[21] Hartmann H. T., Kester, D. E., Davies, F. T. and Genve, R. I. (2007). Hartmann and Kester's plant propagation, principles and practices (7th edition). Prentice-Hall of India Private limited pp880.

[22] International Institute of Tropical Agriculture (IITA), (1982). Selected methods of soil and plant analysis. IITA Manual series, No. 7. IITA, Ibadan, Nigeria

[23] Joffe, P. (2003). Plant Africa: Kigelia africana. http://en.wikipedia.org/wiki/kigelia. Accessed on 07/05/ 2016.

[24] Klingman, G.C. (1977). Crop production in the south. John Wiley and sons Inc. London; Pg.424.

[25] Nelson, D.W. and Summer, L.E. (1982).Total carbon, organic carbon and organic mater.I A.L.Page (ed). Method of soil analysis part 2. Agronomy monograph, No.9 AM soil Agron. Madison,W.I.. Pp 539-579.

[26] Okoruwa A.E., Klingman J.G. (1996). Nutrition and quality of maize. International Institute of Tropical Agriculture (IITA), Ibadan, Nigeria. Research and Training (2nd edition) Guide 33.

[27] Olabode, O.S; Ogunyemi Sola, Akanbi, W.B; Adesina, G.O and P.A. Babajide (2007). Evaluation of Tithonia diversifolia (Hems.l) A Gray for Soil Improvement. World Journal of Agricultural Sciences 3 (4); 503-507.

[28] Olatunji, O.O.; Aderinola, O.A.; Babajide, P.A.; Lawal, B.A.; Owoade, F.M.; Oyeyiola, Y.B.; and A.O. Olayiwola (2012). Effect of poultry manure on soil physico-chemical properties, aggregate stability and biomass yield of Panicum maximum. International Journal of Current Research. Vol.4 (04): 013- 016.

[29] Ombo, F. I. (1994). Self-sufficiency in local fertilizer production for Nigeria. In Proceeding of the 3rd African Soil Science Conference, (August 20 - 23, 1994) at University of Ibadan, Ibadan, Nigeria. pp. 112-114. 
[30] Oyerinde, R.O., Otusanya, O.O., Akpor, O.B. (2009): Allelopathic effect of Tithonia diversifolia on the germination, growth and chlorophyll contents of maize (Zea mays L.). Scientific Research and Essay 4(12):1553-1558.

[31] Page, A.L., Miler, R.H. and Keenery D.R. (1982).Method of Soil Analysis Part 2, Chemical and Microbial Properties. ASA Madison.

[32] Roodt V. (1992). Kigelia africana in the shell field, guide to the common trees of the Okavango Delta and Moremi game reserves, Bostwana: Shell Oil Bostwana. http://en.wikipedia.org/wiki/kigelia. Accessed on 02/09/ 2016.33. SAS (2013).

[33] Sas Institute Inc., Cary Nc., U.S.A. (Software Statistical Programme 2013).

[34] Taiwo, L.B. and Makinde, J.O. (2005): Influence of water extract of Mexican sunflower (Tithonia diversifolia) on growth of cowpea (Vigna unguiculata). African Journal of Biotechnology 4(4):355-360.

*Corresponding author.

E-mail address: pababajide@ lautech.ed.ng /akinbabajide@ yahoo.com 